
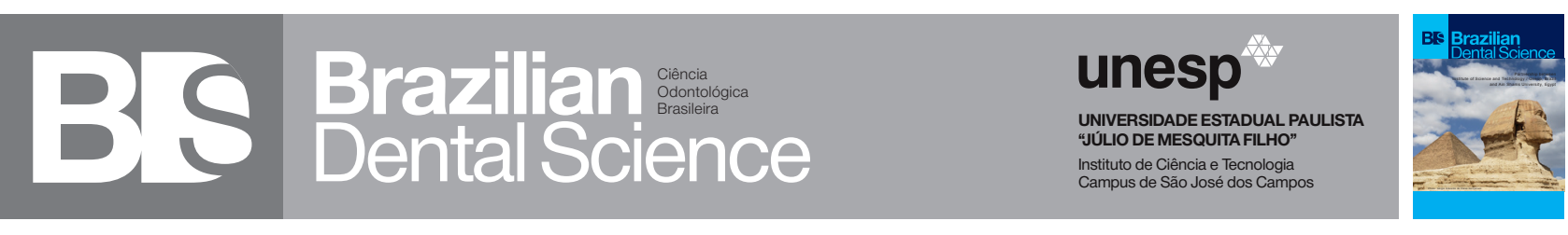

\title{
Dentists' Preferences in the Treatment of Congenitally Missing Maxillary Lateral Incisors
}

\author{
Preferências entre os Dentistas no Tratamento da Agenesia de Incisivos Laterais Superiores \\ Nuha Abdulazeem Mohammed ABDULRAHMAN ${ }^{1}$, Nadia KHALIFA ${ }^{2}$, Mohammed Nasser ALHAJJ ${ }^{1,3}$ \\ 1 - Department of Oral Rehabilitation - Faculty of Dentistry - University of Khartoum - Khartoum - Sudan. \\ 2 - Department of Preventive and Restorative Dentistry - University of Sharjah - Sharjah - United Arab Emirates. \\ 3 - Department of Prosthodontics - Faculty of Dentistry - Thamar University - Dhamar - Yemen.
}

\section{ABSTRACT}

Objective: Congenitally missing maxillary lateral incisors present challenges to dentists in terms of treatment planning and can negatively affect aesthetics and function in patients. The aim of the present study was to determine the preferred treatment approach of dentists with different specialties. Material and Methods: We carried out a descriptive, cross-sectional study using a questionnaire that was self-administered to 12 specialists in removable prosthodontics, 18 specialists in restorative dentistry, 14 specialists in orthodontics, and 173 registered general dentists. Results: General practitioners (72.7\%), prosthodontists $(92.9 \%)$ and, restorative dentists (80\%) preferred prosthodontic replacement of missing maxillary lateral incisors, while orthodontists (57.1\%) preferred canine substitution. Most general practitioners $(62.7 \%)$, prosthodontists $(71.4 \%)$, and orthodontists $(92.9 \%)$, as well as many restorative specialists (40\%), preferred implant-retained crowns for prosthetic replacement of missing lateral incisors. The dental specialties differed significantly in terms of their preferred modalities for treating children over the age of 12 years. General practitioners (56\%) preferred removable partial dentures (RPDs), while a mere $17.2 \%$ preferred to carry out no treatment. All prosthodontists (100\%) preferred treatment with RPDs. Restorative dentists preferred RPDs and adhesive bridges in equal number $(33.3 \%$ in each case). Fifty percent of orthodontists treating children with missing lateral incisors preferred RPDs, followed by $(28.6 \%)$ who preferred canine substitution. Conclusion: Preference varied for several reasons among dentists' treating both adults and children over 12 years of age.

\section{KEYWORDS}

Maxillary missing teeth; Dentist's preference; Teeth replacement; Dental implant.

\section{RESUMO}

Objetivo: A agenesia de incisivos laterais superiores apresenta desafios aos cirurgiões-dentistas em termos de planejamento terapêutico e pode afetar negativamente a estética e a função dos pacientes. O objetivo do presente estudo foi determinar a abordagem de tratamento preferencial entre os dentistas de diferentes especialidades. Material e Métodos: Realizouse um estudo descritivo, transversal, utilizando um questionário autoadministrado por 12 especialistas em prótese dentária removível, 18 especialistas em dentística, 14 especialistas em Ortodontia e 173 dentistas clínicos gerais. Resultados: Clínicos gerais (72,7\%), protesistas $(92,9 \%)$ e especialistas em dentística (80\%) preferiram a substituição protética dos incisivos laterais superiores ausentes, enquanto os ortodontistas $(57,1 \%)$ preferiram a substituição canina. A maioria dos clínicos gerais $(62,7 \%)$, protesistas $(71,4 \%)$ e ortodontistas $(92,9 \%)$, bem como muitos especialistas em dentística (40\%), preferem coroas implantadas para a substituição protética dos incisivos laterais ausentes. As especialidades odontológicas diferiram significativamente em termos de suas modalidades preferidas para o tratamento de crianças com idade acima de 12 anos. Clínicos gerais (56\%) preferiram próteses parciais removíveis (PPRs), enquanto apenas $17,2 \%$ preferiram não realizar nenhum tratamento. Todos os protesistas (100\%) preferiram o tratamento com PPRs. Especialistas em dentística preferiram PPRs e pontes adesivas em igual número (33,3\% em cada caso). Metade dos ortodontistas (50\%) que tratam crianças com incisivos laterais ausentes preferiram PPRs, seguido por (28,6\%) que preferiram a substituição canina. Conclusão: A preferência variou por várias razões entre os dentistas que tratam adultos e crianças com mais de 12 anos de idade.

\section{PALAVRAS-CHAVE}

Dentes superiores ausentes; Preferência do dentista; Substituição de dentes; Implante dentário. 


\section{INTRODUCTION}

C linicians agree that the prevalence of tooth agenesis has increased over the last decade, [1] resulting in a notable increase in the need for orthodontic and prosthodontic treatment. In addition, this demand may be due to a higher perception rate of malocclusions, as well as a greater attention to aesthetics. Agenesis of the maxillary lateral incisors is one of the most commonly treated of these disorders, [2] probably because the absence of these teeth creates aesthetic and functional problems. Since the maxillary lateral incisor is in the anterior aesthetic zone, it presents challenges to dentists in terms of treatment planning and mechanotherapy. Clinicians differ in their treatment of missing maxillary lateral incisors; some prefer canine substitution, whereby they close the space by moving the canine and then shape it to look like a lateral incisor. Others prefer to open and maintain the space so that they can restore the missing lateral incisor prosthodontically-either by tooth-supported restoration or dental implant [3-5].

However, these treatment options are not suitable for all patients, and an appropriate treatment plan must be formulated in each case. The individual characteristics of the teeth, malocclusion, facial features, and the patient's expectations and objectives need to be considered [6]. Furthermore, before commencing treatment, dentists should know the end result and explain the different treatment alternatives to the patient (and/or their parents), with the advantages and disadvantages of each, so that an informed decision can be made. To integrate and coordinate a comprehensive treatment plan and not limit treatment to an isolated specialty, clinicians must adopt a multidisciplinary approach. In addition, careful consideration of patients' expectations can lead to a successful outcome and patient satisfaction $[7,8]$.

Patients with congenitally missing maxillary lateral incisors are almost always concerned about their treatment and want to be satisfied with the outcome because the teeth are located in an integral part of the aesthetic zone. For this reason, dentists must be familiar with the treatment options available and permit patient choice based on the advantages, disadvantages, indications, and contraindications of each treatment. Congenitally missing maxillary lateral incisors are seldom mentioned in textbooks and are mostly managed on the basis of dentists' personal experiences. Thus, specialists such as prosthodontists and orthodontists, as well as general dentists, could be biased towards treatment plans that are based on their own practice or training. They might choose procedures they are more comfortable with and be unaware of the multidisciplinary approach that is necessary in such cases.

The present study might help inform dentists about the different treatment options available and highlight the multidisciplinary approach that is necessary to treat congenitally missing maxillary lateral incisors. The aim of the study was to explore dentists' treatment preferences and to determine which factors may affect, in the opinion of dentists, treatment planning and results.

\section{MATERIAL AND METHODS}

This was a descriptive, cross-sectional study conducted among registered dental practitioners during the period from May to Sep. 2012. Specifically, the study included specialists in removable prosthodontics, restorative dentistry, and orthodontics, as well as general dental practitioners. The subjects were selected by systematic random sampling and comprised: 29 specialists in removable prosthodontics, 42 specialists in restorative dentistry, 33 specialists in orthodontics, and 402 general dentists practicing and working in different areas. The sample size was calculated using the following equation:

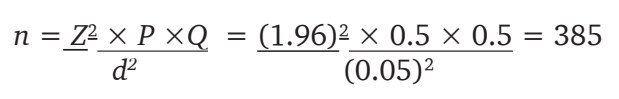

$n=$ sample size, $P=$ prevalence (the estimated proportion of an attribute that is present in the population; 0.5), $Q=1-\mathrm{P}$ (0.5), $Z=$ constant of normal distribution (confidence limits; 1.96), and $d=$ sample error (0.05). 
For convenience, the sample size was reduced according to the following equation

$$
n i=\frac{n}{1+(n / N)}=\frac{385}{1+(385 / 506)}=218
$$

Where: $n i=$ reduced sample size, $\mathrm{n}$ = original sample size (385), and $N=$ total population (506).

The sample size for different disciplines was divided according to the percentage of the total population, as presented in Table 1. Data were collected using a direct method (selfadministered questionnaire), as prepared in the Armbruster's study [9]. We modified the questionnaire to suit the present study. Ten percent of all participants were asked to fill in the questionnaire again after 2 weeks to evaluate the validity of the participants' answers. A significant association between the questionnaires was obtained. A letter explaining the aim of the study accompanied the questionnaire. Data were analyzed using SPSS version 17. An approval letter was obtained from the Ethical Committee prior to the start of the study, and verbal informed consent was obtained from all participants.

Table 1- Distribution of dentists according to specialty in SMC register and after sample size reduction

\begin{tabular}{|c|c|c|}
\hline Qualification & $\begin{array}{c}\text { Population size } \\
\text { according to } \\
\text { SMC }\end{array}$ & $\begin{array}{c}\text { Sample size after } 2^{\text {nd }} \text { calcu- } \\
\text { lation of reduction }\end{array}$ \\
\hline General practitioners & $\mathrm{N}^{1}=402$ & 174 \\
\hline Prosthodontists & $\mathrm{N}^{2}=29$ & 12 \\
\hline Restorative dentists & $\mathrm{N}^{3}=42$ & 18 \\
\hline Orthodontists & $\mathrm{N}^{4}=33$ & 14 \\
\hline Total & $\mathrm{N}=506$ & 218 \\
\hline
\end{tabular}

\section{RESULTS}

Among the 218 questionnaires distributed, 194 were returned, constituting a response rate of $89 \%$. More women than men participated in the study $(60.8 \%$ vs. $39.2 \%) ; 77.8 \%$ of respondents were general practitioners, $7.2 \%$ were prosthodontists (removable), 7.7\% were restorative dentists, and $7.2 \%$ were orthodontists (Table 2). More than half of the participants $(58.8 \%)$ had less than 5 years' experience. The majority of specialists were academic staff, while most of the general practitioners were in governmental dental facilities. Most of the general practitioners (72\%), prosthodontists (92\%), and restorative dentists (80\%) preferred prosthodontic replacement of missing maxillary lateral incisors, while orthodontists $(57.1 \%)$ preferred canine substitution (orthodontic movement of the canine into the space), although there was no significant difference among the groups (P $>0.05)$. Most general practitioners (62.7\%) preferred to replace missing lateral incisors with an implant-retained crown, followed by $15.3 \%$ who preferred cantilever bridges. The majority of prosthodontists (71.4\%) preferred the implant-retained crown, followed by $28.6 \%$ who preferred adhesive bridges. Forty percent of restorative specialists preferred the implant-retained crown, $26.7 \%$ preferred adhesive bridges, and $20.0 \%$ preferred conventional bridges, while only $13.3 \%$ preferred cantilever bridges. The majority of orthodontists (92.9\%) preferred the implantretained crown, followed by $7.1 \%$ who preferred conventional bridges. Moreover, no significant differences were found among the groups $(P=0.118)$ when prosthodontic replacement was indicated.

Table 2 - Characteristics of dentists who responded

\begin{tabular}{|c|c|c|c|}
\hline & & \\
\hline & & Frequency & Percentage \\
\hline \multirow{2}{*}{ Gender } & Male & 76 & 39.2 \\
\hline & Female & 118 & 60.8 \\
\hline \multirow{4}{*}{ Qualification } & General practitioners & 151 & 77.8 \\
\hline & Prosthodontists & 14 & 7.2 \\
\hline & Restoratives & 15 & 7.7 \\
\hline & Orthodontists & 14 & 7.2 \\
\hline \multirow{3}{*}{$\begin{array}{c}\text { Years of } \\
\text { experience }\end{array}$} & «5years & 114 & 58.8 \\
\hline & $5-10$ years & 40 & 20.6 \\
\hline & »10 years & 40 & 20.6 \\
\hline
\end{tabular}

Regarding treatment options in children, a significant difference was found among the groups $(P=0.018)$. Fifty six percent of general practitioners preferred removable partial dentures, followed by (17.2\%) who preferred to carry out no treatment. All prosthodontists (100\%) preferred treatment with removable partial dentures. Restorative dentists preferred 
removable partial dentures and adhesive bridges in equal number (33.3\% in each case). Fifty percent of orthodontists preferred removable partial dentures, followed by $28.6 \%$ who preferred canine substitution (Table 3). Most dentists cited aesthetics or both aesthetics and function as the main reasons for replacing lateral incisors. A small percentage of general dentists chose function only as the main reason for replacing lateral incisors. No significant differences were noted regarding the reasons for replacement of missing lateral incisors. However, a highly significant difference $(\mathrm{P}<0.001)$ was found with regard to the average normal mesiodistal width of the maxillary lateral. The majority of general practitioners (50.7\%) and many prosthodontists (42.9\%) estimated that the average width of lateral incisors is $4-5 \mathrm{~mm}$, while $53.3 \%$ of restorative dentists estimated that it is 5-6 $\mathrm{mm}$ and $71.4 \%$ of orthodontists estimated that it is $6-7 \mathrm{~mm}$. Thirty nine percent of general practitioners placed dental implants, and 35.1\% were interested in doing so in future. Fifty seven percent of prosthodontists placed dental implants, whereas only $14.3 \%$ were interested in doing so in future. Sixty percent of restorative dentists placed dental implants, while a mere $13.3 \%$ were interested in doing so in future. Fifty percent of orthodontists placed dental implants, and 7.1\% wished to do so in future. In this regard, there was a significant difference in the responses among the different groups $(\mathrm{P}=0.007)$. A high percentage (78.6\%) of prosthodontists were familiar with implant restoration in their dental practice. Forty percent of restorative specialists performed implant restoration. General dentists (37.6\%) and orthodontists (35\%) were nearly equal in their practice of implant restoration. Most dentists $(88.1 \%)$ agreed that a multidisciplinary approach was necessary, with no significant difference in response among the groups $(\mathrm{P}=0.364$; Table 3$)$.

The majority of dentists stated that research was the first reason for their use of implant-retained crowns (61\%), and many (42.9\%) gave the same reason for their use of conventional fixed bridges. In the case of adhesive bridges (58.6\%) and cantilever bridges (40\%), the choice was based most often on the conservation of tooth structure. Regarding removable partial dentures, the choice was based on personal experience (50\%) and conservation of tooth structure (50\%).

Conservation of tooth structure was the second reason $(54.9 \%)$ that dentists selected treatment using implant-retained crowns; the same reason prompted $40 \%$ of dentists to choose adhesive bridges. In the case of cantilever bridges, ease of treatment was the second reason for selection (40\%), while personal experience and ease of treatment (30\% in both cases) were the second reasons dentists chose the conventional fixed bridge.

The first reason for the selection of the removable partial denture in children was the age of the patient $(44.1 \%)$; the same reason prompted dentists to use adhesive bridges (42.9\%) and to eschew treatment (71.9\%). The first reason given for treatment using canine substitution was conservation of tooth structure $(31.8 \%)$. For $70 \%$ of the respondents, the choice of implant was based on research. The second reason given for all treatment options in children was the age of the patient.

In the question "Could proper aesthetics be achieved if lateral incisors were restored prosthodontically?" the majority of dental specialists agreed that prosthetic replacements confer good aesthetic results. Furthermore, most general practitioners and restorative dentists thought that canine substitution could not achieve good aesthetic results, while prosthodontists and orthodontists thought the opposite. Responses to the question "Could proper function be achieved if lateral incisors were restored prosthodontically?" revealed that most dental specialists agreed that prosthetic replacements confer good functional results. The majority of prosthodontists and orthodontists thought that canine substitution can achieve good functional results.

When responses to the questions in Table 3 were grouped according to the dentists' years of experience, the only significant difference $(P=0.035)$ among the groups occurred in the response to the question "If a prosthodontic replacement were indicated, which one would you prefer?" About $64.9 \%$ of dentists with less than 5 years' experience preferred implant-retained crowns, followed by $15.8 \%$ who preferred adhesive bridges. Meanwhile, $71.8 \%$ of dentists with $5-10$ years' experience preferred implant-retained crowns, followed by $12.8 \%$ who preferred adhesive bridges. However, $52.5 \%$ of dentists with more than 10 years' experience preferred implant-retained crowns, followed by $20 \%$ who preferred conventional fixed bridges (Table 4). 
Table $\mathbf{3}$ - Responses of dentists according to their qualification

\begin{tabular}{|c|c|c|c|c|c|c|c|}
\hline Question & Chosen Answer & $\begin{array}{c}\text { General } \\
\text { practitioners }\end{array}$ & $\begin{array}{l}\text { Prosthodon- } \\
\text { tists }\end{array}$ & $\begin{array}{l}\text { Restorative } \\
\text { Dentists }\end{array}$ & $\begin{array}{l}\text { Orthodon- } \\
\text { tists }\end{array}$ & Total & $\mathbf{P}$ \\
\hline & & $N(\%)$ & $N(\%)$ & $N(\%)$ & $N(\%)$ & $N(\%)$ & \\
\hline \multirow{4}{*}{$\begin{array}{l}\text { How do you manage missing } \\
\text { lateral incisors? }\end{array}$} & Prosthodontic replacement & $109(72.7)$ & $13(92.9)$ & $12(80)$ & $6(42.9)$ & $140(72.5)$ & \multirow{4}{*}{0.057} \\
\hline & Canine substitution & $29(19.3)$ & $1(7.1)$ & $2(13.3)$ & $8(57.1)$ & $40(20.7)$ & \\
\hline & No treatment & $6(4.0)$ & $0(0.0)$ & $0(0.0)$ & $0(0.0)$ & $6(3.1)$ & \\
\hline & Idon'tknow & $6(4.0)$ & $0(0.0)$ & $1(6.7)$ & $0(0.0)$ & $7(3.6)$ & \\
\hline \multirow{5}{*}{$\begin{array}{l}\text { If prosthodontic replacement } \\
\text { were indicated, which one would } \\
\text { you prefer? }\end{array}$} & RPD & $2(1.3)$ & $0(0.0)$ & $0(0.0)$ & $0(0.0)$ & $2(1.0)$ & \multirow{5}{*}{0.118} \\
\hline & FPD & $10(6.7)$ & $0(0.0)$ & $3(20.0)$ & $1(7.1)$ & $14(7.3)$ & \\
\hline & Cantilever bridge & $23(15.3)$ & $0(0.0)$ & $2(13.3)$ & $0(0.0)$ & $25(13.0)$ & \\
\hline & Adhesive bridge & $21(14.0)$ & $4(28.6)$ & $4(26.7)$ & $0(0.0)$ & $29(15.0)$ & \\
\hline & Implant-retained crown & $94(62.7)$ & $10(71.4)$ & $6(40.0)$ & $13(92.9)$ & $123(63.7)$ & \\
\hline \multirow{6}{*}{$\begin{array}{l}\text { If the patient were a child } \\
\text { (e.g.12 years old), which op- } \\
\text { tions would you prefer? }\end{array}$} & Canine substitution & $18(11.9)$ & $0(0.0)$ & $0(0.0)$ & $4(28.6)$ & $22(11.3)$ & \multirow{6}{*}{0.018} \\
\hline & RPD & $85(56.3)$ & $14(100.0)$ & $5(33.3)$ & $7(50.0)$ & $111(57.2)$ & \\
\hline & Cantilever bridge & $4(2.6)$ & $0(0.0)$ & $0(0.0)$ & $0(0.0)$ & $4(2.1)$ & \\
\hline & Adhesive bridge & $15(9.9)$ & $0(0.0)$ & $5(33.3)$ & $1(7.1)$ & $21(10.8)$ & \\
\hline & Implant-retained crown & $3(2.0)$ & $0(0.0)$ & $1(6.7)$ & $0(0.0)$ & $4(2.1)$ & \\
\hline & No treatment & $26(17.2)$ & $0(0.0)$ & $4(26.7)$ & $2(14.3)$ & $32(16.5)$ & \\
\hline \multirow{3}{*}{$\begin{array}{l}\text { What is the main reason for } \\
\text { replacing missing lateral incisor? }\end{array}$} & Esthetic & $71(47.0)$ & $10(71.4)$ & $9(60.0)$ & $7(50.0)$ & $97(50.0)$ & \multirow{3}{*}{0.585} \\
\hline & Function & $5(3.3)$ & $0(0.0)$ & $0(0.0)$ & $0(0.0)$ & $5(2.6)$ & \\
\hline & Both & $75(49.7)$ & $4(28.6)$ & $6(40.0)$ & $7(50.0)$ & $92(47.4)$ & \\
\hline \multirow{4}{*}{$\begin{array}{l}\text { What is the average mesiodistal } \\
\text { width of normal maxillary lateral } \\
\text { incisor? }\end{array}$} & $4-5 \mathrm{~mm}$ & $76(50.7)$ & $6(42.9)$ & $5(33.3)$ & $0(0.0)$ & $87(45.1)$ & \multirow{4}{*}{0.000} \\
\hline & $5-6 \mathrm{~mm}$ & $51(34.0)$ & $4(28.6)$ & $8(53.3)$ & $3(21.4)$ & $66(34.2)$ & \\
\hline & $6-7 \mathrm{~mm}$ & $19(12.7)$ & $4(28.6)$ & $2(13.3)$ & $10(71.4)$ & $35(18.1)$ & \\
\hline & $7-8 \mathrm{~mm}$ & $4(2.7)$ & $0(0.0)$ & $0(0.0)$ & $1(7.1)$ & $5(2.6)$ & \\
\hline \multirow{4}{*}{$\begin{array}{l}\text { Do you surgically place dental } \\
\text { implants? }\end{array}$} & Yes & $32(21.2)$ & $8(57.1)$ & $9(60.0)$ & $5(35.7)$ & $54(27.8)$ & \multirow{4}{*}{0.007} \\
\hline & No & $60(39.7)$ & $3(21.4)$ & $3(20.0)$ & $7(50.0)$ & $73(37.6)$ & \\
\hline & Not yet & $53(35.1)$ & $2(14.3)$ & $2(13.3)$ & $1(7.1)$ & $58(29.9)$ & \\
\hline & Not interested & $6(4.0)$ & $1(7.1)$ & $1(6.7)$ & $1(7.1)$ & $9(4.6)$ & \\
\hline \multirow{4}{*}{$\begin{array}{l}\text { Are you familiar with restoring } \\
\text { dental implants? }\end{array}$} & Yes & $56(37.6)$ & $11(78.6)$ & $6(40.0)$ & $5(35.7)$ & $78(40.6)$ & \multirow{4}{*}{0.364} \\
\hline & No & $53(35.6)$ & $1(7.1)$ & $5(33.3)$ & $5(35.7)$ & $64(33.3)$ & \\
\hline & Not yet & $38(25.5)$ & $2(14.3)$ & $4(26.7)$ & $4(28.6)$ & $48(25.0)$ & \\
\hline & Not interested & $2(1.3)$ & $0(0.0)$ & $0(0.0)$ & $0(0.0)$ & $2(1.0)$ & \\
\hline \multirow{2}{*}{$\begin{array}{l}\text { Does management of such } \\
\text { cases require a multidisciplinary } \\
\text { approach? }\end{array}$} & Yes & $130(86.7)$ & $13(92.9)$ & $13(86.7)$ & $14(100.0)$ & $170(88.1)$ & \multirow[b]{2}{*}{0.473} \\
\hline & No & $20(13.3)$ & $1(7.1)$ & $2(13.3)$ & $0(0.0)$ & $23(11.9)$ & \\
\hline
\end{tabular}


Table 4 - Responses of dentists according to their clinical experience

\begin{tabular}{|c|c|c|c|c|c|c|}
\hline Question & Chosen Answer & $\begin{array}{l}<5 \text { years of } \\
\text { experience }\end{array}$ & $\begin{array}{l}5-10 \text { years of } \\
\text { experience }\end{array}$ & $\begin{array}{l}>10 \text { years of } \\
\text { experience }\end{array}$ & Total & \multirow{2}{*}{$\mathbf{P}$} \\
\hline & & $N(\%)$ & $N(\%)$ & $N(\%)$ & $N(\%)$ & \\
\hline \multirow{4}{*}{$\begin{array}{l}\text { How do you manage missing } \\
\text { lateral incisors? }\end{array}$} & Prosthodontic replacement & $85(74.6)$ & $25(64.1)$ & $30(75.0)$ & $140(72.5)$ & \multirow{4}{*}{0.746} \\
\hline & Canine substitution & $21(18.4)$ & $10(25.6)$ & $9(22.5)$ & $40(20.7)$ & \\
\hline & No treatment & $4(3.5)$ & $2(5.1)$ & $0(0.0)$ & $6(3.1)$ & \\
\hline & Idon'tknow & $4(3.5)$ & $2(5.1)$ & $1(2.5)$ & $7(3.6)$ & \\
\hline \multirow{5}{*}{$\begin{array}{l}\text { If prosthodontic replacement } \\
\text { were indicated, which one would } \\
\text { you prefer? }\end{array}$} & RPD & $0(0.0)$ & $1(2.6)$ & $1(2.5)$ & $2(1.0)$ & \multirow{5}{*}{0.035} \\
\hline & FPD & $5(4.4)$ & $1(2.6)$ & $8(20.0)$ & $14(7.3)$ & \\
\hline & Cantilever bridge & $17(14.9)$ & $4(10.3)$ & $4(10.0)$ & $25(13.0)$ & \\
\hline & Adhesive bridge & $18(15.8)$ & $5(12.8)$ & $6(15.0)$ & $29(15.0)$ & \\
\hline & Implant-retained crown & $74(64.9)$ & $28(71.8)$ & $21(52.5)$ & $123(63.7)$ & \\
\hline \multirow{6}{*}{$\begin{array}{l}\text { If the patient were a child } \\
\text { (e.g.12 years old) which options } \\
\text { would you prefer? }\end{array}$} & Canine substitution & $16(14.0)$ & $4(10.0)$ & $2(5.0)$ & $22(11.3)$ & \multirow{6}{*}{0.080} \\
\hline & RPD & $60(52.6)$ & $27(67.5)$ & $24(60.0)$ & $111(57.2)$ & \\
\hline & Cantilever bridge & $4(3.5)$ & $0(0.0)$ & $0(0.0)$ & $4(2.1)$ & \\
\hline & Adhesive bridge & $12(10.5)$ & $3(7.5)$ & $6(15.0)$ & $21(10.8)$ & \\
\hline & Implant-retained crown & $0(0.0)$ & $1(2.5)$ & $3(7.5)$ & $4(2.1)$ & \\
\hline & No treatment & $22(19.3)$ & $5(12.5)$ & $5(12.5)$ & $32(16.5)$ & \\
\hline \multirow{3}{*}{$\begin{array}{l}\text { What is the main reason for re- } \\
\text { placing missing lateral incisors? }\end{array}$} & Esthetic & $55(48.2)$ & $22(55.0)$ & $20(50.0)$ & $97(50.0)$ & \multirow{3}{*}{0.755} \\
\hline & Function & $2(1.8)$ & $1(2.5)$ & $2(5.0)$ & $5(2.6)$ & \\
\hline & Both & $57(50.0)$ & $17(42.5)$ & $18(45.0)$ & $92(47.4)$ & \\
\hline \multirow{4}{*}{$\begin{array}{l}\text { What is the average mesiodistal } \\
\text { width of normal maxillary lateral } \\
\text { incisor? }\end{array}$} & $4-5 \mathrm{~mm}$ & $55(48.2)$ & $18(46.2)$ & $14(35.0)$ & $87(45.1)$ & \multirow{4}{*}{0.754} \\
\hline & $5-6 \mathrm{~mm}$ & $36(31.6)$ & $13(33.3)$ & $17(42.5)$ & $66(34.2)$ & \\
\hline & $6-7 \mathrm{~mm}$ & $21(18.4)$ & $7(17.9)$ & $7(17.5)$ & $35(18.1)$ & \\
\hline & $7-8 \mathrm{~mm}$ & $2(1.8)$ & $1(2.6)$ & $2(5.0)$ & $5(2.6)$ & \\
\hline \multirow{4}{*}{$\begin{array}{l}\text { Do you surgically place dental } \\
\text { implants? }\end{array}$} & Yes & $26(22.8)$ & $16(40.0)$ & $12(30.0)$ & $54(27.8)$ & \multirow{4}{*}{0.221} \\
\hline & No & $43(37.7)$ & $13(32.5)$ & $17(42.5)$ & $73(37.6)$ & \\
\hline & Not yet & $41(36.0)$ & $8(20.0)$ & $9(22.5)$ & $58(29.9)$ & \\
\hline & Not interested & $4(3.5)$ & $3(7.5)$ & $2(5.0)$ & $9(4.6)$ & \\
\hline \multirow{4}{*}{$\begin{array}{l}\text { Are you familiar with restoring } \\
\text { dental implants? }\end{array}$} & Yes & 44 (38.9) & $21(52.5)$ & $13(33.3)$ & $78(40.6)$ & \multirow{4}{*}{0.334} \\
\hline & No & $35(31.0)$ & $12(30.0)$ & $17(43.6)$ & $64(33.3)$ & \\
\hline & Not yet & $33(29.2)$ & $7(17.5)$ & $8(20.5)$ & $48(25.0)$ & \\
\hline & Not interested & $1(0.9)$ & $0(0.0)$ & $1(2.6)$ & $2(1.0)$ & \\
\hline $\begin{array}{l}\text { Does management t of such } \\
\text { cases require a multidisciplinary } \\
\text { approach? }\end{array}$ & Yes & $101(88.6)$ & $36(90.0)$ & $33(84.6)$ & $170(88.1)$ & 0.735 \\
\hline
\end{tabular}




\section{DISCUSSION}

Treatment of congenitally missing lateral incisors is crucial because missing teeth adversely affect facial appearance and personal behavior [10]. Successful treatment of patients with this condition, from the point of view of both dentists and patients, depends on correct decision-making by dentists. The aim of the present study was to assess dentists' preferences in the treatment of congenitally missing lateral incisor and their preferences of prosthetic for the replacement of a single missing tooth. Clinicians prefer the most conservative and aesthetic approach when treating missing teeth, especially those in the aesthetic zone. In the present context, response to the questionnaires was good (88.9\%). Among specialists, response was $100 \%$, while among general dentists it was $86.7 \%$. The lower response rate among practicing general dentists may be due to their focus on provision of care rather than on research.

No significant differences were found among dentists of different specialties in regard to which treatment approach they preferred when replacing the missing lateral incisor. As expected, most general dentists, prosthodontists, and restorative dentists preferred prosthetic replacement of congenitally missing maxillary lateral incisors, while orthodontists preferred to substitute the lateral incisor orthodontically using the canine. This may be because dentists lack sufficient knowledge about canine substitution as an alternative to prosthetic replacement, or because they assume from experience that shaping the canine to simulate a lateral incisor will not achieve optimum results. These findings were similar to those of Armbruster et al [9]. Clinical decision making relies on factors such as scientific knowledge clinical experience as well as individual preferences $[11,12]$. In the present study, general dentists, prosthodontists, and restorative specialists placed more emphasis on the aesthetic rather than the functional aspect of treatment outcome. Conversely, orthodontists gave equal importance to aesthetics and function. This also corroborates the findings of Armbruster et al [9], wherein more general dentists and specialists than orthodontists opted to restore the lateral incisor for aesthetic reasons. The majority of participants agreed that prosthetic replacements could achieve better aesthetic and functional results similar to other study [9]. However this result was not significant.

With regards to the aesthetics and function of canine substitution, no statistically significant results were obtained. These findings indicate that continuous education and training would benefit dentists, allowing them to acknowledge canine substitution as a treatment alternative to prosthodontic therapy [13].

The use of implants is a predictable treatment option substantiated by a number of clinical investigations [14,15], and patients with congenitally missing lateral incisors are satisfied with this treatment modality [16]. The present study reflected this, because most respondents believed that implant-retained crowns represented the most preferable treatment option. Even though there were no significant differences among the dental specialties in terms of their preferred prosthetic options, there were significant differences depending on the respondents' experience. This may indicate that dentists are kept upto-date, but that it is unlikely that they really practice the latest treatment. In the present study, dentists based their decisions about prosthetic treatment options on the following factors (in decreasing order of importance): on research, conservation of tooth structure, personal experience, ease of treatment, patient desire, finance, and oral hygiene. The dentists' first choice of implant was based on research, and their second was based on conservation of tooth structure. In children with missing lateral incisors, the choice of treatment is restricted to either canine substitution, space maintenance using removable partial dentures or a fixed adhesive bridge [17], or no treatment [18]. In the present study, there was a significant difference among the 
dental specialties in terms of their preferred treatment modalities in children over the age of 12 years. All prosthodontists preferred to treat missing lateral incisors in children using removable partial dentures, while only half of general practitioners chose removable partial dentures, and nearly one fifth of them opted for no treatment. Restorative specialists chose to restore the space using removable partial dentures or adhesive bridges in equal proportion. Half of the orthodontists chose removable partial dentures, while under a third of them preferred canine substitution. These findings indicate that dentists prefer the most conservative and least invasive procedures when treating children. In the present study, a significant difference was observed among the dentists with regards to treatment options in children and the reasons for them. Most based their decision on removable partial dentures on the age of the patient, followed by research, personal experience, conservation of tooth structure, and finally financial grounds.

In the present study, general dentists and orthodontists were less likely to carry out implant therapy than prosthodontists and restorative specialists. Implant therapy, unlike simple bridge work, requires special training that is not included in most undergraduate dental programs. Furthermore, because there is limited access to postgraduate programs in Sudan, implant therapy is not within the practice realm of all dentists [15]. The majority of dentists in the present study agreed that treatment of congenitally missing lateral incisors requires a multidisciplinary approach to ensure optimal results that satisfy both patients and dentists. This is in agreement with Matthew's study [19] Restoring congenitally missing lateral incisors requires comprehensive treatment planning and knowledge of the treatment alternatives. The information reported in this study could help guide dentists when discussing treatment options with patients who have congenitally missing lateral incisors. Further studies should be carried to investigate whether dentists actually practice their preferred treatment. Continuous education and training of dentists about the treatment options available would ultimately benefit patients.

\section{CONCLUSION}

Within the limitations of this study it can be concluded that:

Dentists varied in their treatment preferences for adults and children with congenitally missing lateral incisors. There were several reasons for the variation in the dentists' decision regarding prosthetic replacement in adult patients.

\section{REFERENCES}

1. Mattheeuws N, Dermaut L, Martens G. Has hypodontia increased in caucaians during the 20th century ameta analysis. Eur J Orthod. 2004 Feb;26(1):99-103.

2. Polder BJ, Van't Hof MA, Van der Linden FP, Kuijpers-Jagtman AM. A meta-analysis of the prevalence of dental agenesis of permanent teeth. Community Dent Oral Epidemiol. 2004 Jun;32(3):217-26.

3. Millar BJ, Taylor NG. Lateral thinking: The managment of missing upper lateral incisors. Br Dent J. 1995 Aug 5;179(3):99-106.

4. Sabri R. Management of missing maxillary lateral incisors. J Am Dent Assoc. 1999 Jan;130(1):80-4.

5. Kokich VO Jr, Kinzer GA, Janakievski J. Congenitally missing maxillary lateral incisors: Restorative replacement. Am J Orthod Dentofacial Orthop. 2011 Apr;139(4):435, 437, 439 passim. doi: 10.1016/j. ajodo.2011.02.004.

6. Richardson G, Russell KA. Congenitally missing maxillary lateral incisors and orthodontic treatment considerations for the single-tooth implant. J Can Dent Assoc. 2001 Jan;67(1):25-8.

7. Thomas B. Management of a patient with congenitally missing lateral incisor: amultidisciplinary team approach. Rev Clín Pesq Odontol. 2009;5:293-9.

8. Aktas G, Canay S, Aktas A, El H, Bayramov I. Interdisciplinary approach for congenitally missing maxillary lateral incisors. Internet J Dent Sci. 2010;8(2):1-5.

9. Armbruster PC, Gardiner DM, Whitley JB Jr, Flerra J. The congenitally missing maxillary lateral incisor. Part 2: assessing dentists' preferences for treatment. World J Orthod. 2005 Winter;6(4):376-81.

10. Hobkirk JA, Goodman JR, Jones SP. Presenting complaints and findings in a group of patients attending a hypodontia clinic. Br Dent $\mathrm{J}$. 1994 Nov 5;177(9):337-9.

11. McCreery AM, Truelove E. Decision making in dentistry. Part II: Clinical applications of decision methods. J Prosthet Dent. 1991 Apr;65(4):57585. 
12. Rosa M, Olimpo A, Fastuca R, Caprioglio A. Perceptions of dental professionals and laypeople to altered dental esthetics in cases with congenitally missing maxillary lateral incisors. Prog Orthod. 2013 Oct 1;14:34. doi: 10.1186/2196-1042-14-34.

13. De-Marchi LM, Pini NI, Ramos AL, Pascotto RC. Smile attractiveness of patients treated for congenitally missing maxillary lateral incisors as rated by dentists, laypersons, and the patients themselves. J Prosthet Dent. 2014 Sep;112(3):540-6. doi: 10.1016/j.prosdent.2014.01.019. Epub 2014 Apr 13.

14. Anderson KM, Behrents RG, McKinney T, Buschang PH. Tooth shape preferences in an esthetic smile. Am J Orthod Dentofacial Orthop. 2005 0ct;128(4):458-65.
15. Hebel K, Gajjar R, Hofstede T. Single-tooth replacement: Bridge vs. implant-supported restoration. J Can Dent Assoc. 2000 Sep;66(8):435-8.

16. Robertsson S, Mohlin B. The congenitally missing upper lateral incisor. A retrospective study of orthodontic space closure versus restorative treatment. Eur J Orthod. 2000 Dec;22(6):697-710.

17. Uribe F, Meiers JC, Nanda R. Fixed retention of congenitally missing maxillary lateral incisors using a chairside, prefabricated fiberreinforced composite bridge. World J Orthod. 2008 Winter;9(4):349-54.

18. Wexler G. Missing upper lateral incisors: orthodontic considerations in young patients. Ann R Australas Coll Dent Surg. 2000 0ct;15:136-40.

19. Matthews DC. Decision making in periodontics: A review of outcome measures. J Dent Educ. 1994 Aug;58(8):641-7.

\section{Mohammed Nasser Alhajj}

(Corresponding address)

Department of Oral Rehabilitation,

Faculty of Dentistry, University of Khartoum,

Khartoum, Sudan

Date submitted: 2018 Dec 22

Email: m.n.alhajj@hotmail.com 